\title{
Mean Platelet Volume/Platelet Count Ratio as a Diagnostic Marker in Children with Acute Appendicitis
}

\section{Inanc Karakoyun $\odot$ Mustafa Onur Oztan ๑}

\author{
Akut Apandisitli Çocuklarda Tanısal Belirteç Olarak \\ Ortalama Trombosit Hacmi/Trombosit Sayısı Oranı
}

\section{ABSTRACT}

Objective: The objective of this research was to evaluate the diagnostic value of mean platelet volume/ platelet count (MPV/PC) ratio in pediatric acute appendicitis.

Methods: This retrospective study included a total of 310 patients, 176 in the uncomplicated appendicitis group, 80 in the complicated appendicitis group, and 54 in the nonspecific abdominal pain (NSAP) group. $C$-reactive protein (CRP) level, white blood cell (WBC) count, absolute neutrophil count (ANC), MPV, PC, and MPV/PC ratio were compared between the groups.

Results: WBC and ANC levels differed significantly between the groups $(P<0.001$ in all pairwise comparisons). CRP levels in the complicated appendicitis group were higher than in the NSAP and uncomplicated appendicitis groups ( $P<0.001$ for both comparisons). There was a negative correlation between MPV and PC ( $r=-0.434, P<0.001)$. Both $P C$ and MPV/PC ratio were able to distinguish cases of complicated appendicitis from NSAP ( $P=0.047$ and $P=0.045$, respectively) and from cases of uncomplicated appendicitis ( $P=0.010$ and $P=0.045$, respectively). Areas under the ROC curve for CRP, WBC, ANC, MPV, $P C$, and MPV/PC ratio were $0.640,0.690,0.727,0.553,0.541$, and 0.546 , respectively.

Conclusion: According to the results of our study, MPV/PC ratio can be used in addition to the conventional markers to discriminate cases of complicated appendicitis.

Keywords: Appendicitis, biomarkers, mean platelet volume/platelet count ratio, pediatrics

öz

Amaç: Bu çalışmanın amacı pediatrik akut apandisitte ortalama trombosit hacmi/trombosit sayısı (MPV/ $P C)$ oranının tanısal değerini değerlendirmektir.

Yöntem: Bu retrospektif çalışma, komplike olmayan apandisit grubunda 176, komplike apandisit grubunda 80 ve nonspesifik karın ağrısı (NSAP) grubunda 54 olmak üzere toplam 310 hastayı içermektedir. C-reaktif protein (CRP) düzeyi, beyaz kan hücresi sayısı (WBC), mutlak nötrofil sayısı (ANC), MPV, PC ve MPV/PC oranı gruplar arasında karşılaştırıldı.

Bulgular: WBC ve ANC düzeyleri gruplar arasında anlamlı farklılık gösterdi (tüm ikili karşılaştırmalarda $P<0.001)$. Komplike apandisit grubunda CRP düzeyleri NSAP ve komplike olmayan apandisit gruplarından daha yüksekti (her iki karşılaştırma için de $P<0.001$ ). MPV ve $P C$ arasında negatif bir korelasyon vardı $(r=-0.434, P<0.001)$. Hem PC hem de MPV/PC oranı, komplike apandisit vakalarını NSAP (sırasıyla $P=0.047$ ve $P=0.045$ ) ve komplike olmayan apandisit vakalarından (sirasıly $P=0.010$ ve $P=0.045$ ) ayırt edebildi. $C R P$, $W B C, A N C, M P V, P C$ ve MPV/PC oranı için ROC eğrisi altındaki alanlar, sırasıyla 0.640, 0.690, 0.727, 0.553, 0.541 ve 0.546 'dır.

Sonuç: Çalışmamızın sonuçlarına göre, komplike apandisit vakalarını ayırt etmek için geleneksel belirteçlere ek olarak MPV/PC oranı kullanılabilir.

Anahtar kelimeler: Apandisit, biyobelirteçler, ortalama trombosit hacmi/trombosit sayısı oranı, pediatri
Received: 06.05 .2020

Accepted: 03.06 .2020

Published Online: 30.04 .2021

Cite as: Karakoyun I, Oztan MO. Mean platelet volume/platelet count ratio as a diagnostic marker in children with acute appendicitis. İzmir Dr. Behçet Uz Çocuk Hast. Dergisi. 2021;11(1):87-93.

Inanc Karakoyun Sağı̆ık Bilimleri Üniversitesi, Tepecik Eğitim ve Araştırma Hastanesi, Tıbbi Biyokimya Bölümü, İzmir, Türkiye inanckara70@hotmail.com ORCID: 0000-0002-7057-171X

M.O. Oztan 0000-0003-3696-4090 Izmir Katip Çelebi Üniversitesi, Çocuk Cerrahisi Anabilim Dalı, izmir Türkiye 


\section{INTRODUCTION}

Acute abdominal pain in children is a common cause of emergency department (ED) admissions and represents a challenge for physicians who conduct the initial evaluation ${ }^{(1)}$. Although acute abdominal pain is usually a self-limiting process, in a small proportion of cases (1-8\%) it is associated with a serious condition that requires surgery, such as appendicitis ${ }^{(1,2)}$.

Acute appendicitis is the most common abdominal surgical emergency in the pediatric population ${ }^{(3)}$ and an early diagnosis can reduce the incidence of perforation, postoperative complications, mortality, length of hospital stay, and costs ${ }^{(4)}$. However, early diagnosis of appendicitis is a challenging issue even today, because the clinical signs and symptoms presented in the ED may be nonspecific and misleading, particularly in younger children ${ }^{(5)}$.

Although ultrasound and computed tomography (CT) have improved diagnostic accuracy in acute appendicitis, these imaging modalities have some disadvantages ${ }^{(6)}$. CT has over $95 \%$ sensitivity and specificity in the diagnosis of acute appendicitis, but also requires exposing children to ionizing radiation ${ }^{(7)}$. Abdominal ultrasound also offers good specificity and specificity ( $88 \%$ and $94 \%$, respectively) without the negative effects of radiation, but its diagnostic value is operator-dependent ${ }^{\left({ }^{8}\right)}$.

In recent years, biomarkers have been used in addition to imaging techniques as noninvasive tools for diagnosing disease and predicting prognosis ${ }^{(9)}$. White blood cell (WBC) count, absolute neutrophil count (ANC), and C-reactive protein (CRP) are traditional parameters routinely use either alone or in combination by physicians in ED ${ }^{(10)}$. However, the diagnostic sensitivity and specificity values reported for these markers are highly variable, raising questions regarding their ability to enable physicians to accurately and reliably rule out or confirm the diagnosis of acute appendicitis (11). Although leukocytosis is present in $70 \%$ of patients with acute appendicitis, the presence of leukocytosis in other acute abdominal complaints decreases the sensitivity and specificity of this test ${ }^{(12)}$. In addition, large fluctuations in CRP sensitivity (40-99\%) and specificity (27-90\%) led researchers to seek new biomarkers ${ }^{(13)}$.

Platelet indices including mean platelet volume (MPV) and platelet count $(\mathrm{PC})$ are routinely reported parameters in complete blood count ( $C B C$ ) analysis and have been investigated for the diagnosis of acute appendicitis, but the results are variable ${ }^{(14-17)}$. It has been suggested that there is an inverse relationship between these two parameters and that their ratio, rather than their individual values, is superior in terms of diagnostic potential (18).

Our aim in the present study was to evaluate the utility of MPV/PC ratio in pediatric patients presenting to the ED with suspected acute appendicitis. To the best of our knowledge, MPV/PC ratio has not been evaluated previously in suspected acute appendicitis in the pediatric population.

\section{MATERIAL and METHOD}

\section{Subjects and study design}

This retrospective study was conducted in patients who presented to the ED of a tertiary hospital between January 1, 2016 and January 1, 2019 with complaints of abdominal pain. A total of 310 patients under 18 years of age were included in the study. Three groups were formed: nonspecificabdominal pain (NSAP), uncomplicated appendicitis, and complicated appendicitis. The NSAP group consisted of patients with nonspecific abdominal pain who were observed for 24 to 48 hours and discharged $(n=54)$. The NSAP patients were contacted by phone after discharge to ensure that appendicitis did not develop. Patients with obvious symptoms of urinary tract infection, gastroenteritis, and respiratory system infections were excluded from the study. Patients who underwent appendectomy and were confirmed as having focal, suppurative, or phlegmonous appendicitis in the pathology report were included in the uncomplicated appendicitis group ( $n=176)$. Those whose appendectomy pathology report indicated gangrenous or perforated appendicitis were included in the complicated appendicitis group $(n=80)$. Patients with negative appendectomy and other surgical pathologies were excluded from the uncomplicated and complicated appendicitis groups.

\section{Analyzed laboratory parameters}

CRP, WBC, ANC, MPV, and PC results were obtained from the laboratory information system, and MPV/PC ratio was calculated from MPV and PC values. Analysis of WBC, $A N C, M P V$, and $P C$, which are $C B C$ subparameters, were 
performed by electrical impedance method (Coulter $\mathrm{LH}$ 780, Beckman Coulter Inc., CA, USA); CRP was analyzed turbidimetrically by an automated procedure (AU640 autoanalyzer, Beckman Coulter Inc., CA, USA). Total coefficient of variation was $<3.3$ for $C B C$ parameters, and $<5$ for CRP.

\section{Statistical analysis}

SPSS version 22.0 (SPSS Inc., Chicago, USA) software package was used for statistical analyses. Results of the Shapiro-Wilk test indicated that the data were not normally distributed, and the nonparametric MannWhitney $U$ test was used for statistical analyses. Chisquare test was used for sex-based comparison of the groups. Results were given as median (interquartile range).
Cut-off, sensitivity, specificity, and area under the curve (AUC) values of the analyzed markers were determined by receiver operating characteristic (ROC) curve analysis. Correlations between the laboratory markers were identified with Spearman rank correlation test. Results with $\mathrm{P}<0.05$ were considered statistically significant.

\section{Ethical considerations}

The study was approved by the local ethics committee (Resolution Number 2019/8-11, dated May 08, 2019).

\section{RESULTS}

The demographic characteristics and laboratory findings of the patients with acute appendicitis and those

Table 1. The demographic characteristics and laboratory findings of patients with acute appendicitis and those with nonspecific abdominal pain.

\begin{tabular}{|c|c|c|c|c|}
\hline Parameter & $\begin{array}{l}\text { NSAP } \\
(n=54)\end{array}$ & $\begin{array}{l}\text { Uncomplicated appendicitis } \\
\qquad(n=176)\end{array}$ & $\begin{array}{l}\text { Complicated appendicitis } \\
\qquad(n=80)\end{array}$ & $\mathbf{P}$ \\
\hline Age, years & $13.0(9.0-15.0)$ & $11.0(8.0-14.0)$ & $11.0(8.0-14.0)$ & $\begin{array}{l}0.131^{*} \\
0.156^{\dagger} \\
0.738^{\ddagger}\end{array}$ \\
\hline $\begin{array}{l}\text { Gender } \\
\text { Female, } \mathrm{n}(\%)\end{array}$ & 28 (51.9\%) & 59 (33.5\%) & 29 (36.3\%) & 0.050 \\
\hline $\mathrm{WBC}\left(\times 10^{3} / \mu \mathrm{L}\right)$ & $11.6(8.6-16.8)$ & $14.9(12.4-18.8)$ & $17.9(14.7-21.5)$ & $\begin{array}{l}<0.001^{*} \\
<0.001^{\dagger} \\
<0.001^{\ddagger}\end{array}$ \\
\hline $\operatorname{ANC}\left(x 10^{3} / \mu \mathrm{L}\right)$ & $7.4(5.2-12.5)$ & $12.3(9.1-15.7)$ & $15.2(12.6-18.3)$ & $\begin{array}{l}<0.001^{*} \\
<0.001^{\dagger} \\
<0.001^{\ddagger}\end{array}$ \\
\hline MPV (fL) & $8.0(7.5-8.7)$ & $7.9(7.4-8.5)$ & $7.9(7.2-8.7)$ & $\begin{array}{l}0.587^{*} \\
0.315^{+} \\
0.519^{\ddagger}\end{array}$ \\
\hline $\mathrm{PC}\left(\times 10^{3} / \mu \mathrm{L}\right)$ & $285.5(237.5-375.0)$ & $295.0(251.5-343.0)$ & $319.0(272.8-384.3)$ & $\begin{array}{l}0.750^{*} \\
0.047^{+} \\
0.010^{\ddagger}\end{array}$ \\
\hline MPV/PC & $0.0296(0.0208-0.0363)$ & $0.0271(0.0222-0.0341)$ & $0.0264(0.0200-0.0305)$ & $\begin{array}{l}0.645^{*} \\
0.045^{+} \\
0.045^{\ddagger}\end{array}$ \\
\hline
\end{tabular}

*NSAP vs. Uncomplicated appendicitis; +NSAP vs. Complicated appendicitis; $¥$ Uncomplicated appendicitis vs. Complicated appendicitis; Data were presented as median $\left(25^{\text {th }}-75^{\text {th }}\right.$ percentile); $P$ value $<0.05$ was considered statistically significant; Statistically significant $P$ values shown in bold.

Abbr: NSAP, Nonspecific abdominal pain; $n$, number; WBC, White blood cell count; ANC, Absolute neutrophil count; CRP, C-reactive protein; MPV, Mean platelet volume; PC, Platelet count. 
with NSAP are summarized in Table 1. There was no difference in age between the groups (NSAP vs. uncomplicated appendicitis $p=0.131$, NSAP vs. complicated appendicitis $p=0.156$, uncomplicated appendicitis vs. complicated appendicitis $p=0.738)$. There was no difference in sex distribution between the three groups $(P=0.050)$.

PC levels in the complicated appendicitis group were higher than in the other two groups (NSAP vs. complicated appendicitis $p=0.047$, uncomplicated appendicitis vs. complicated appendicitis $\mathrm{p}=0.010)$.

The median value of our candidate marker MPV/PC ratio was 0.0296 in the NSAP, 0.0271 in the uncomplicated appendicitis, and 0.0264 in the complicated appendicitis group. These median values were able to distinguish cases of complicated appendicitis from NSAP $(p=0.045)$ and uncomplicated appendicitis cases $(p=0.045)$.

$W B C$ and $A N C$, markers routinely used in the diagnosis of acute appendicitis, showed significant differences in all pairwise comparisons $(p<0.001)$. CRP levels were also higher in the complicated appendicitis group than in the other two groups (NSAP vs. complicated appendicitis $\mathrm{P}<0.001$, uncomplicated appendicitis vs. complicated appendicitis $\mathrm{p}<0.001$ ).

The diagnostic capacities of the laboratory markers were evaluated using ROC curve analysis (Table 2, Figure 1). The AUC of ANC indicated good discrimination between NSAP and acute appendicitis (AUC=0.727, $p<0.001$ ), while the AUC of WBC and CRP showed fair discrimination ( $A \cup C=0.690, P<0.001 ; A \cup C=0.640, P<0.001$, respectively). AUC of MPV, PC, and MPV/PC ratio showed poor discrimination $(A \cup C=0.553, p=0.424 ; A U C=0.541, p=0.391$; and $A \cup C=0.546, p=0.336$, respectively) ${ }^{(19)}$.
According to Spearman correlation analysis, there was a negative correlation between MPV and PC ( $r=-0.434$, $\mathrm{P}<0.001$ ) (Table 3).

\section{DISCUSSION}

There is an ongoing debate regarding the usefulness of laboratory tests in the diagnosis of acute appendicitis (20). In this study, we evaluated the diagnostic value of MPV/PC ratio in children with acute appendicitis, which to the best of our knowledge is the first examination of this parameter for acute appendicitis in this age group.

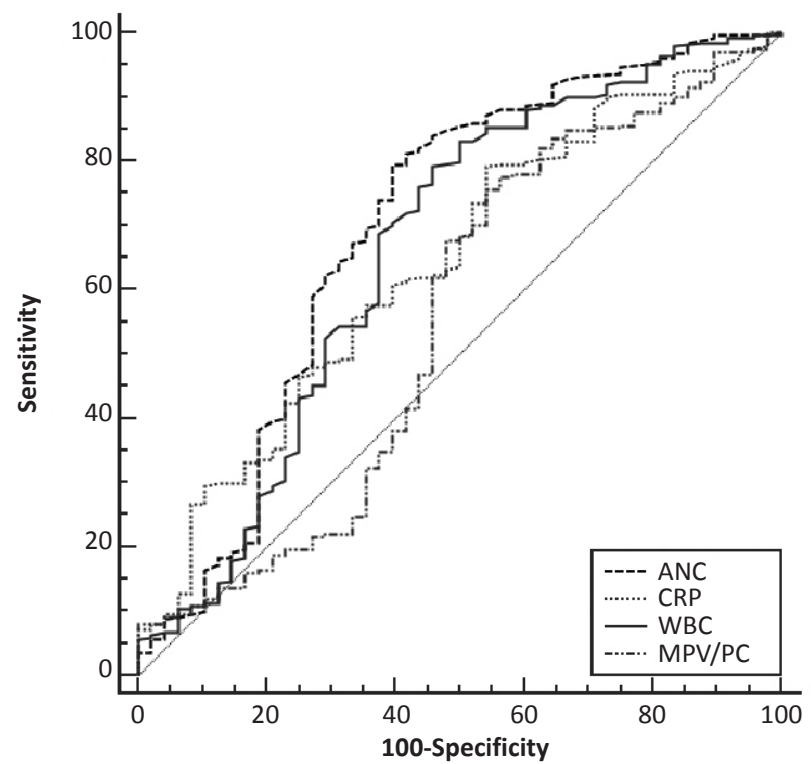

Figure 1. Receiver operating characteristic curves of markers for discrimination of patients with acute appendicitis and those with nonspecific abdominal pain.

Abbr: WBC, White blood cell; ANC, Absolute neutrophil count; $C R P, C$-reactive protein; MPV, Mean platelet volume; PC, Platelet count.

Table 2. Cut-off values and diagnostic performance characteristics of markers in the differential diagnosis of patients with acute appendicitis and those with nonspecific abdominal pain.

\begin{tabular}{|c|c|c|c|c|c|c|c|}
\hline & Cut-off value & Sensitivity, (\%) & $95 \% \mathrm{Cl}$ & Specificity (\%) & $95 \% \mathrm{Cl}$ & AUC $(95 \% \mathrm{CI})$ & $\mathbf{P}^{*}$ \\
\hline WBC $\left(\times 10^{3} / \mu \mathrm{L}\right)$ & $>11.9$ & 83.6 & $78.5-87.9$ & 55.6 & $41.4-69.1$ & $0.690(0.635-0.741)$ & $<0.001$ \\
\hline ANC $\left(x 10^{3} / \mu \mathrm{L}\right)$ & $>9.5$ & 79.3 & $73.8-84.1$ & 64.8 & $50.6-77.3$ & $0.727(0.674-0.776)$ & $<0.001$ \\
\hline $\mathrm{CRP}(\mathrm{mg} / \mathrm{L})$ & $>4.7$ & 79.2 & $73.6-84.1$ & 45.8 & $31.4-60.8$ & $0.640(0.582-0.694)$ & $<0.001$ \\
\hline MPV (fL) & $\leq 7.1$ & 15.6 & $11.4-20.7$ & 94.4 & $84.6-98.8$ & $0.553(0.476-0.589)$ & 0.424 \\
\hline $\mathrm{PC}\left(\mathrm{x} 10^{3} / \mu \mathrm{L}\right)$ & $>257$ & 74.2 & $68.4-79.5$ & 44.4 & $30.9-58.6$ & $0.541(0.484-0.598)$ & 0.391 \\
\hline $\mathrm{MPV} / \mathrm{PC}$ & $\leq 0.0320$ & 73.8 & $68.0-79.1$ & 44.4 & $30.9-58.6$ & $0.546(0.489-0.603)$ & 0.336 \\
\hline
\end{tabular}

* Significance of AUC; $P$ value $<0.05$ was considered statistically significant; Statistically significant $P$ values shown in bold.

Abbr: Cl, Confidence interval; WBC, White blood cell; ANC, Absolute neutrophil count; CRP, C-reactive protein; MPV, Mean platelet volume; PC, Platelet count; AUC, Area under curve. 
Table 3. Correlations of markers that evaluated in the diagnosis of acute appendicitis.

\begin{tabular}{lcccccc}
\hline Markers & ANC & CRP & MPV & PC & MPV/PC \\
\hline WBC & $r$ & 0.948 & 0.614 & -0.160 & 0.284 & -0.273 \\
& $P$ & $<0.001$ & $<0.001$ & $<0.001$ & 0.496 & $<0.001$ \\
ANC & $r$ & & 0.643 & -0.102 & 0.217 & -0.201 \\
& $P$ & & $<0.001$ & 0.023 & $<0.001$ & $<0.001$ \\
CRP & $r$ & & & -0.155 & 0.080 & -0.104 \\
& $P$ & & & 0.001 & 0.098 & 0.032 \\
MPV & $r$ & & & & -0.434 & 0.702 \\
& $P$ & & & & $<0.001$ & $<0.001$ \\
PC & $r$ & & & & & -0.937 \\
& $P$ & & & & & $<0.001$
\end{tabular}

$P$ value $<0.05$ was considered statistically significant; Statistically significant $P$ values shown in bold.

Abbr: WBC, White blood cell count; ANC, Absolute neutrophil count; CRP, C-reactive protein; MPV, Mean platelet volume; PC, Platelet count; $r$, Correlation coefficient.

MPV and PC are among the 18 to 22 subparameters determined in $\mathrm{CBC}$ analysis, depending on the analyzer used. The utility of MPV/PC ratio has been investigated in many diseases including hepatocellular carcinoma, lung cancer, obstructive sleep apnea syndrome, and acute ischemic stroke ${ }^{(21-24)}$. The interest in platelets and related indices is based primarily on growing evidence of their key role in inflammation. Platelets have been shown to produce and store large amounts of inflammatory mediators, communicate with and activate different cells, and are themselves activated by various proinflammatory mediators via surface receptors ${ }^{(25)}$. In our study, the higher platelet counts in patients with complicated appendicitis compared to NSAP support the role of platelets in the inflammatory process. Another finding of our study was that the group with the most severe inflammation had the highest CRP and PC levels.

MPV, a measure of platelet size, is one of the most widely used markers of platelet function and is believed to reflect the inflammatory burden in various diseases ${ }^{(26)}$. Different mechanisms have been proposed to explain the relationship between MPV and the inflammatory process. Interleukin (IL)-6 is a well-known acute phase reactant inducer whose concentration correlates with CRP and degree of inflammation, and higher IL- 6 levels have been demonstrated in acute appendicitis ${ }^{(27,28)}$. It has been hypothesized that conditions associated with high inflammatory marker activity may also decrease MPV values, and thus decreased MPV may indicate the intensity of the inflammatory process. Overproduction of proinflammatory cytokines and acute phase reactants may suppress platelet size by inhibiting megakaryopoiesis, resulting in the release of small platelets from the bone marrow ${ }^{(28)}$. In the present study, we observed lower MPV levels in the appendicitis groups compared to the NSAP group, but the differences were not statistically significant.

There is only one study in the literature evaluating MPV/PC ratio in acute appendicitis, which was conducted in adults. Biricik et al. detected no difference in MPV/PC ratio between healthy controls and acute appendicitis cases ${ }^{(29)}$. In contrast to their findings, we determined in the present study that changes in MPV and especially PC ultimately affected the MPV/PC ratio in complicated appendicitis. Although the decrease in MPV was not significant in patients with complicated appendicitis, this change was found to affect the significance of MPV/PC ratio, albeit to a limited degree. According to our results, MPV/PC ratio at a cut-off value of 0.0320 was able to distinguish cases of acute appendicitis from NSAP with $73.8 \%$ sensitivity and $44.4 \%$ specificity. We also noted an inverse correlation between MPV and PC.

Leukocyte count is commonly used in the diagnosis of acute appendicitis, with high leukocyte count recognized as helpful in the early diagnosis of acute appendicitis. On the other hand, ANC is usually associated with bacterial infections. In previous studies, sensitivity and specificity of WBC were reported as $67-97.8 \%$ and $31.9-90.8 \%$, and those of ANC as 68.6-98.9\% and 33.191\%, respectively. In our study, WBC and ANC levels were high in the acute appendicitis group and consistent with the literature ${ }^{(14)}$.

CRP is another frequently used test to guide clinical evaluation of acute appendicitis. It is an acute phase reactant that is synthesized in the liver and released into the bloodstream in response to tissue damage. CRP measurement is practical, fast, and cost-effective. Previous studies in the literature have reported a sensitivity of $40-94 \%$ and specificity of $38-87 \%{ }^{(30)}$. In our study, CRP was elevated in patients with complicated appendicitis and its diagnostic sensitivity and specificity values were consistent with the literature. Despite low sensitivity and specificity, one of the main findings of our study is that the traditional 
markers (CRP, WBC, and ANC) had better AUC and $P$ values, thus remaining the first choice to distinguish complicated appendicitis cases from NSAP.

There are several limitations of this study. First, there were fewer cases of NSAP and complicated appendicitis than uncomplicated appendicitis during the study period. We were able to contact only a small number of patients after discharge due to reasons such as having an incorrect phone number on file or getting no response, which reduced the size of our NSAP group. Second, similar to other retrospective studies, we cannot completely rule out the impact of selection bias.

In conclusion, early diagnosis of acute appendicitis in children is important to reduce morbidity and mortality rates. According to the results of our study, MPV/PC ratio can be used in addition to traditional markers as a guide for ED physicians to discriminate cases of complicated appendicitis.

Ethics Committee Approval: Approval was obtained from the ethics committee of Tepecik Training and Research Hospital with decision number 2019/8-11.

Conflict of Interest: The Authors declare that there is no conflict of interest.

Funding: This research did not receive any specific grant from funding agencies in the public, commercial, or not-for-profit sectors.

Informed Consent: Since our study was retrospective, informed consent was not obtained from the patients.

\section{REFERENCES}

1. Míguez C, Tomatis Souverbielle C, Haro A, Guerrero G, PérezEgidoL,García-Gamiz M, etal.Evaluation of proadrenomedullin as a diagnostic or prognostic biomarker of acute appendicitis in children. Am J Emerg Med. 2016;34(12):2298-305. https://doi.org/10.1016/j.ajem.2016.08.032

2. Almaramhy $\mathrm{HH}$. Acute appendicitis in young children less than 5 years: review article. Ital J Pediatr. 2017;43(1):15. https://doi.org/10.1186/s13052-017-0335-2

3. Glass CC, Rangel SJ. Overview and diagnosis of acute appendicitis in children. Semin Pediatr Surg. 2016;25(4):198203.

https://doi.org/10.1053/j.sempedsurg.2016.05.001

4. Galai T, Beloosesky OZ, Scolnik D, Rimon A, Glatstein M. Misdiagnosis of Acute Appendicitis in Children Attending the Emergency Department: The Experience of a Large, Tertiary Care Pediatric Hospital. Eur J Pediatr Surg. 2017;27(2):13841. https://doi.org/10.1055/s-0035-1570757

5. Caruso AM, Pane A, Garau R, Atzori P, Podda M, Casuccio A, et al. Acute appendicitis in children: not only surgical treatment. J Pediatr Surg. 2017;52(3):444-8.

https://doi.org/10.1016/j.jpedsurg.2016.08.007

6. Monsalve S, Ellwanger A, Montedonico S. White blood cell count and C-reactive protein together remain useful for diagnosis and staging of acute appendicitis in children. S Afr Med J. 2017;107(9):773-6. https://doi.org/10.7196/SAMJ.2017.v107i9.12206

7. Russell WS, Schuh AM, Hill JG, Hebra A, Cina RA, Smith CD, et al. Clinical practice guidelines for pediatric appendicitis evaluation can decrease computed tomography utilization while maintaining diagnostic accuracy. Pediatr Emerg Care. 2013;29:568-73.

https://doi.org/10.1097/PEC.0b013e31828e5718

8. Estey A, Poonai N, Lim R. Appendix not seen: the predictive value of secondary inflammatory sonographic signs. Pediatr Emerg Care. 2013;29:435-9. https://doi.org/10.1097/PEC.0b013e318289e8d5

9. Benito J, Acedo Y, Medrano L, Barcena E, Garay RP, Arri EA. Usefulness of new and traditional serum biomarkers in children with suspected appendicitis. Am J Emerg Med. 2016;34(5):871-6. https://doi.org/10.1016/j.ajem.2016.02.011

10. Allister L, Bachur R, Glickman J, Horwitz B. Serum markers in acute appendicitis. J Surg Res. 2011;168(1):70-5. https://doi.org/10.1016/j.jss.2009.10.029

11. Huckins DS, Simon HK, Copeland K, Spiro DM, Gogain J, Wandell M. A novel biomarker panel to rule out acute appendicitis in pediatric patients with abdominal pain. Am J Emerg Med. 2013;31(9):1368-75.

https://doi.org/10.1016/j.ajem.2013.06.016

12. Yu CW, Juan LI, Wu MH, Shen CJ, Wu JY, Lee CC. Systematic review and meta-analysis of the diagnostic accuracy of procalcitonin, C-reactive protein and white blood cell count for suspected acute appendicitis. $\mathrm{Br} J$ Surg. 2013;100(3):322-9. https://doi.org/10.1002/bjs.9008

13. Gulnaz N, Tasleem S, Abdullah F, Afzal A. Clinical Accuracy of Inflammatory Markers Combined with Ultrasound in Acute Appendicitis. Ann. Pak. Inst. Med. Sci. 2018;14(2):161-8.

14. Bozkurt S, Köse A, Erdogan S, Bozali GI, Ayrik C, Arpaci RB, et al. MPV and other inflammatory markers in diagnosing acute appendicitis. J Pak Med Assoc. 2015;65(6):637-41.

15. Kucuk E, Kucuk I. Mean Platelet Volume is Reduced in Acute Appendicitis. Turk J Emerg Med. 2015;15(1):23-7. https://doi.org/10.5505/1304.7361.2015.32657

16. Memon AS, Khatoon S, Memon RA, Junejo A. Acute appendicitis; Mean platelet volume. Professional Med J. 2015;22(9):1212-6. https://doi.org/10.17957/TPMJ/15.2827

17. Yilmaz B K, Ayhan ACAR Y. Investigation of the Diagnostic Value of Neutrophil to Lymphocyte Ratio in Pediatric Appendicitis Cases. Iran J Pediatr. 2017;27(3):e9593. https://doi.org/10.5812/ijp.9593

18. Wu YY, Zhang X, Qin YY, Qin JQ, Lin FQ. Mean platelet volume/platelet count ratio in colorectal cancer: a retrospective clinical study. BMC Cancer. 2019;19(1):314. https://doi.org/10.1186/s12885-019-5504-9

19. Carter JV, Pan J, Rai SN, Galandiuk S. ROC-ing along: Evaluation and interpretation of receiver operating characteristic curves. Surgery. 2016;159(6):1638-45. https://doi.org/10.1016/j.surg.2015.12.029 
20. Yang HR, Wang YC, Chung PK, Chen WK, Jeng LB, Chen RJ. Laboratory tests in patients with acute appendicitis. ANZ J Surg. 2006;76:71-4. https://doi.org/10.1111/j.1445-2197.2006.03645.x

21. Cho SY, Yang JJ, You E, Kim BH, Shim J, Lee HJ, et al. Mean platelet volume/platelet count ratio in hepatocellular carcinoma. Platelets. 2013;24(5):375-7. https://doi.org/10.3109/09537104.2012.701028

22. Inagaki N, Kibata K, Tamaki T, Shimizu T, Nomura S. Prognostic impact of the mean platelet volume/platelet count ratio in terms of survival in advanced non-small cell lung cancer. Lung Cancer. 2014;83(1):97-101. https://doi.org/10.1016/j.lungcan.2013.08.020

23. Soyalıç H, Somuk BT, Doğru S, Gürbüzler L, Göktaş G, Eyibilen A. Evaluation of mean platelet volume and its ratio over platelet count in children with obstructive sleep apnea syndrome. The Turkish Journal of Ear Nose and Throat. 2015;25(1):16-21.

https://doi.org/10.5606/kbbihtisas.2015.28863

24. Elsayed AM, Mohamed GA. Mean platelet volume and mean platelet volume/platelet count ratio as a risk stratification tool in the assessment of severity of acute ischemic stroke. Alexandria Journal of Medicine. 2017;53(1):67-70. https://doi.org/10.1016/j.ajme.2016.03.003
25. Danese S, Motte Cd Cde L, Fiocchi C. Platelets in inflammatory bowel disease: clinical, pathogenic, and therapeutic implications. Am J Gastroentrol. 2004;99(5):938-45. https://doi.org/10.1111/j.1572-0241.2004.04129.x

26. Ulasli SS, Ozyurek BA, Yilmaz EB, Ulubay G. Mean platelet volume as an inflammatory marker in acute exacerbation of chronic obstructive pulmonary disease. Pol Arch Med Wewn. 2012;122(6):284-90. https://doi.org/10.20452/pamw.1284

27. Groselj-Grenc M, Repse S, Vidmar D, Derganc M. Clinical and laboratory methods in diagnosis of acute appendicitis in children. Croat Med J. 2007;48(3):353-61.

28. Sert A, Aypar E, Odabas D. Mean platelet volume in acute rheumatic fever. Platelets. 2013;24(5):378-82. https://doi.org/10.3109/09537104.2012.701029

29. Biricik S, NarCı H, Dündar GA, Ayrık C, Türkmenoğlu MÖ. Mean platelet volume and the ratio of mean platelet volume to platelet count in the diagnosis of acute appendicitis. Am J Emerg Med. 2019;37(3):411-4. https://doi.org/10.1016/j.ajem.2018.05.075

30. Kaya B, Sana B, Eris C, Karabulut K, Bat O, Kutanis R. The diagnostic value of $D$-dimer, procalcitonin and CRP in acute appendicitis. Int J Med Sci. 2012;9(10):909-15. https://doi.org/10.7150/ijms.4733 